\title{
Bibliometric analysis of orthopedic theses in Turkey
}

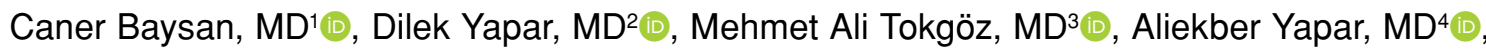 \\ Ebru Kul Baysan, $\mathrm{MD}^{5}$, Tolga Tolunay, $\mathrm{MD}^{3}$ (D) \\ ${ }^{1}$ Department of Public Health, Ankara University Faculty of Medicine, Ankara, Turkey \\ ${ }^{2}$ Department of Public Health, Ministry of Health Antalya Muratpaşa District Health Directorate, Antalya, Turkey \\ ${ }^{3}$ Department of Orthopedics and Traumatology, Gazi University Faculty of Medicine, Ankara, Turkey \\ ${ }^{4}$ Department of Orthopedics and Traumatology, Antalya Training and Research Hospital, Antalya, Turkey \\ ${ }^{5}$ Department of Physical and Rehabilitation Medicine, Etimesgut Şehit Sait Ertürk State Hospital, Ankara, Turkey
}

There has been a significant increase in the number of scientific articles published in recent years. Accordingly, the quantity and quality of the published articles are used to define the level of academic excellence for countries, institutions, and individuals. ${ }^{[1]}$ The impact of the increase in scientific productivity has also been striking in orthopedics and traumatology. In recent years, the distinction between orthopedics sub-specialties has become apparent, and the number of specific journals accepting articles only related to a single field of orthopedics has been multiplied. ${ }^{[2]}$

The advances in scientific productivity have originated from the popularity of teaching and practicing evidence-based medicine methods all

Received: September 05, 2021

Accepted: October 07, 2021

Published online: November 19, 2021

Correspondence: Caner Baysan, MD. Ankara Üniversitesi Tıp Fakültesi, Halk Sağlığı Anabilim Dalı, 06620 Mamak, Ankara, Türkiye.

E-mail: canerbaysan@gmail.com

Doi: $10.52312 / j d r s .2021 .406$

Citation: Baysan C, Yapar D, Tokgöz MA, Yapar A, Kul Baysan E, Tolunay T. Bibliometric analysis of orthopedic theses in Turkey. Jt Dis Relat Surg 2021;32(3):752-758.

(C2021 All right reserved by the Turkish Joint Diseases Foundation

This is an open access article under the terms of the Creative Commons Attribution-NonCommercial License, which permits use, distribution and reproduction in any medium, provided the original work is properly cited and is not used for commercial purposes (http://creativecommons.org/licenses/by-nc/4.0/).

\section{ABSTRACT}

Objectives: This study aims to investigate the topics distribution trend and evaluate the characteristics of orthopedics and traumatology residency theses during a 20 -year period using a bibliometric analysis.

Materials and methods: Between January 2000 and December 2020 , orthopedics and traumatology residency theses of all centers providing postgraduate education in Turkey were reviewed from the online application of the National Thesis Center of Higher Education Council. Using the advanced search screen, a total of 1,907 theses were reached. Massachusetts University Orthopaedics and Traumatology Fellowship Programs and Turkish Society of Orthopaedics and Traumatology sub-study groups.

Results: During the study period, the three most studied topics ones were orthopedic trauma $(\mathrm{n}=536 ; 28.1 \%)$, adult reconstruction and arthroplasty $(n=301 ; 15.8 \%)$ and spine surgery $(n=203 ; 10.6 \%)$. The least studied subject was bone and soft tissue tumors with $3.8 \%(n=73)$. The topic with the highest rate of publication in all years was again orthopedic trauma. There was a very strong positive $(r=0.876)$ correlation between the total number of thesis publications and the years $\left(\mathrm{p}<0.001 ; \mathrm{R}^{2}=0.767\right)$. Based on institutions types, the number of theses published in the training and research hospitals increased as of 2016. More theses were published than expected on orthopedic trauma, adult reconstruction and arthroplasty, sports injuries and arthroscopy, shoulder and elbow surgery, foot and ankle surgery in the training and research hospitals $(\mathrm{p}=0.003)$.

Conclusion: The orthopedic research trends were differentiated over the years in our country. The classification of the orthopedic thesis topics shows in which orthopedics subfield research subjects are concentrated in our country and in which fields, research is needed.

Keywords: Bibliometric analysis, education, orthopedics, theses.

around the world. The most important effect of evidence-based medicine practices on postgraduate education is the use of quantitative research methods 
in theses prepared during residency training. The thesis is based on a research project and is published as open source in many countries for scientific, economic, and ethical reasons. ${ }^{[3]}$

Bibliometrics, a term first described by Pritchard $^{[4]}$ in 1969, is an analysis technique, and its use has increased since 1970 and has taken its place in the literature as a quantitative method that enables statistical analysis of all types of academic documents. ${ }^{[5]}$ Since bibliometric research demonstrates the general trend of the research topics and reveals the literature development in that field, it provides the latest information about current developments and effectively shapes future studies. One of the ways to identify current research trends is to review the topics of the thesis in the relevant field. ${ }^{[6]}$

The number of orthopedics and traumatology residents and accordingly the number of theses has been increasing. Although previous analyses about a similar topic were made by Koca et al., ${ }^{[7]}$ the distribution according to orthopedics subgroups was not examined ${ }^{[8]}$ and the aforementioned authors had access problems to the thesis database. In this study, we aimed to conduct a bibliometric analysis of the theses published within the past 20 years in the field of orthopedics and traumatology according to their topics and features. We hypothesized that there was a change in the thesis topics over the years and based on the institution (university or training and research hospital) where the study was conducted.

\section{MATERIALS AND METHODS}

This cross-sectional study was conducted between January 2000 and December 2020, with specialization theses in the Department of Orthopedics and Traumatology. The study protocol was approved by the Dr. Abdurrahman Yurtaslan Ankara Oncology Training and Research Hospital Ethics Committee (Date: 2020, No: 12/929). Orthopedics and traumatology residency theses of all centers providing postgraduate education in Turkey were reviewed from the online application of the National Thesis Center of Higher Education Council (available at: https://tez.yok.gov.tr/UlusalTezMerkezi). The search strategy was constituted by entering the keywords "Orthopedics and traumatology" in the department line, "Medical residency" in the thesis type line, and "2000-2020" in the date range line of the advanced search screen that could be accessed online. As a result of the search, a total of 1,907 theses were reached, and title, subject, name of the author, name of the advisor, properties of the institution (name and system of service), and the number of pages were recorded. In theses with double advisors, the faculty member with a higher title was taken into consideration.

The thesis topics were determined according to the Massachusetts University Orthopaedics and Traumatology Fellowship Programs and Turkish Society of Orthopaedics and Traumatology sub-study groups. The topics were divided into 10 topics as adult reconstruction and arthroplasty, foot and ankle surgery, hand and upper extremity surgery, orthopedic trauma, pediatric orthopedics, spine surgery, sports injuries, and arthroscopy, bone and soft tissue tumors, shoulder elbow surgery, and general orthopedics. The reviewing process of the theses from the national online database and the subgrouping of the scanned 1,907 theses were made by the committee formed by two orthopedic surgeons and a physiatrist. The members of the committee made decisions in an interdependent manner, and there were no differences of opinion in the decision-making process for the subgroups (Table I).

\section{Statistical analysis}

Statistical analysis was performed using the SPSS for Windows version 25.0 software (IBM Corp., Armonk, NY, USA). Descriptive data were presented in mean \pm standard deviation (SD), median $\left(25^{\text {th }}-75^{\text {th }}\right.$ percentiles $)$ or number and frequency. One-sample chi-square test was conducted to investigate the compatibility of the actual distribution of the categorical data with the expected distribution. The Pearson chi-square test was used to compare categorical data, while the Mann-Whitney $U$ test was used to compare continuous variables. Bonferroni correction was carried out in multiple group comparisons. The Pearson correlation analysis was performed to evaluate the relationships of continuous variables. Correlation coefficients ( $r$ ) was rated as very weak: 0.0-0.19, weak: $0.20-0.39$, moderate: $0.40-0.59$, strong: $0.60-0.79$, and very strong: $0.80-1.00$. A $p$ value of $<0.05$ was considered statistically significant.

\section{RESULTS}

During the study period, $81.3 \% \quad(n=1,551)$ of 1,907 residency theses in the field of orthopedics and traumatology were conducted in the university hospitals, while $18.7 \% \quad(\mathrm{n}=356)$ were in the training and research hospitals. The academic titles of thesis advisors were professors $(\mathrm{n}=948 ; 49.7 \%)$, associate professors $(\mathrm{n}=637 ; 33.4 \%)$, assistant professors $(\mathrm{n}=252 ; 13.2)$, and consultant orthopedic surgeons 


\begin{tabular}{|c|c|}
\hline \multicolumn{2}{|c|}{$\begin{array}{l}\text { TABLE I } \\
\text { The definitions of orthopedics and traumatology subgroups }\end{array}$} \\
\hline Subgroup & Definition \\
\hline Adult reconstruction and arthroplasty & $\begin{array}{l}\text { Hip and knee arthroplasty, peri-prosthesis complications, non-arthroplasty surgeries } \\
\text { for knee and hip osteoarthritis }\end{array}$ \\
\hline Foot and ankle surgery & Foot deformities, hallux disorders, ankle arthroscopy, talus osteochondral defects \\
\hline Hand and upper extremity surgery & $\begin{array}{l}\text { Hand and wrist injuries, brachial plexus palsy, tendon repairs and transfers, skin } \\
\text { grafting and flap surgery, upper extremity amputations }\end{array}$ \\
\hline Orthopedic trauma & Post-traumatic lower and upper extremity fractures and dislocations \\
\hline Pediatric orthopedics & $\begin{array}{l}\text { Pes equinovarus, developmental hip dysplasia, Leg Calve Perthes disease, child } \\
\text { deformities with cerebral palsy sequelae }\end{array}$ \\
\hline Spine surgery & Spine deformities and fractures, scoliosis, and disc pathologies \\
\hline In sports injuries and arthroscopy & Meniscus and knee ligament injuries, tendinopathy, Cartilage damage \\
\hline Bone and soft tissue tumors & Bone and soft tissue tumors and lesions \\
\hline Shoulder and elbow surgery & Shoulder and elbow arthroscopy and arthroplasty, Rotator Cuff pathologies \\
\hline General orthopedics & $\begin{array}{l}\text { Metabolic bone diseases, infectious diseases related to the musculoskeletal system, } \\
\text { and topics that not fit into any group }\end{array}$ \\
\hline
\end{tabular}

$(\mathrm{n}=49 ; 2.6 \%)$. In $21(1.1 \%)$ of theses, the academic title of the advisor was unable to be determined.

Considering the distribution of the subgroups examined in the theses, the three most studied ones were orthopedic trauma $(n=536 ; 28.1 \%)$, adult reconstruction and arthroplasty $(n=301 ; 15.8 \%)$, and spine surgery $(n=203 ; 10.6 \%)$. The least studied topic was bone and soft tissue tumors with $3.8 \% \quad(n=73)$ (Figure 1). Based on the distribution percentages of the theses published according to the years, the topic with the highest rate of publication in all years was again orthopedic trauma. No thesis was completed in 2001 and 2002 under the topic of bone and soft tissue tumors and in 2007 under the topic of hand surgery (Figure 2).

The time distribution graphic of the theses published during the study period is shown in Figure 3. According to the number of the thesis

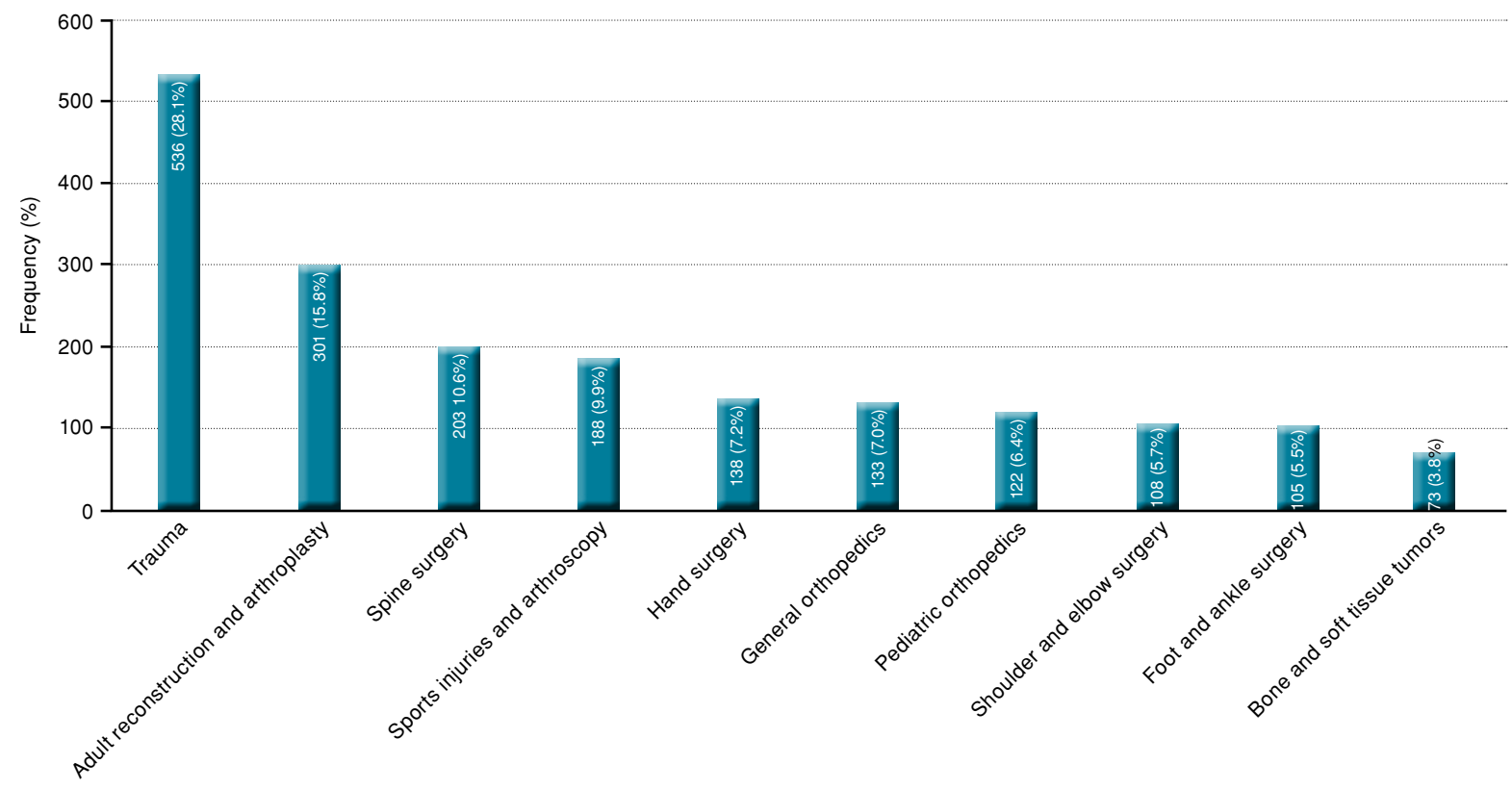




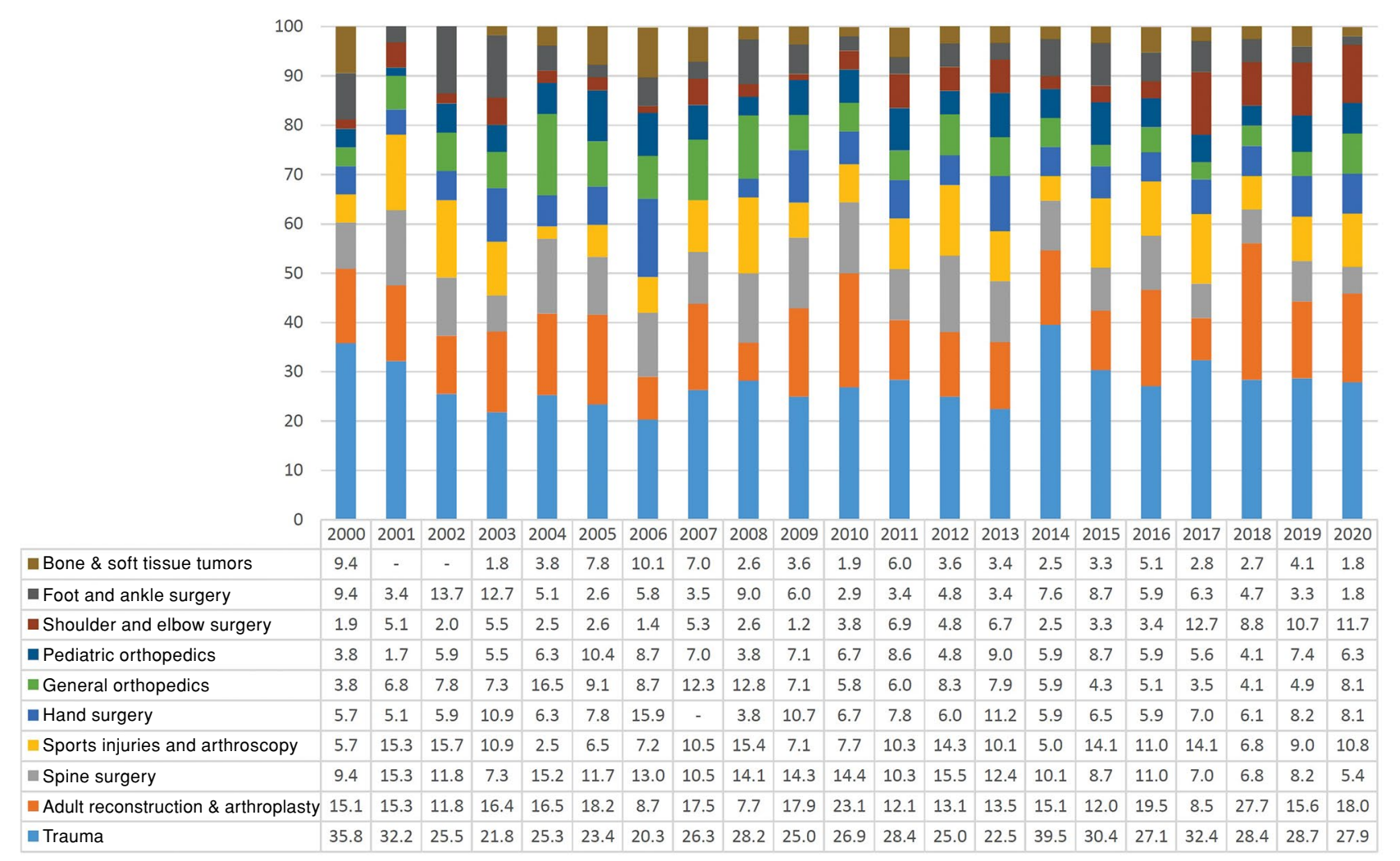

FIGURE 2. Percentage distribution graphic of the theses by years (2000-2020).

by years, the most productive year was 2018 $(n=148 ; 7.8 \%)$, and the least was $2002(n=51 ; 2.7 \%)$. A very strong positive $(\mathrm{r}=0.876)$ correlation was found between the total number of thesis publications and the years $(\mathrm{p}<0.001 ; \mathrm{R} 2=0.767)$. Based on the institution types, the number of theses published in the training and research hospitals increased as of 2016 .

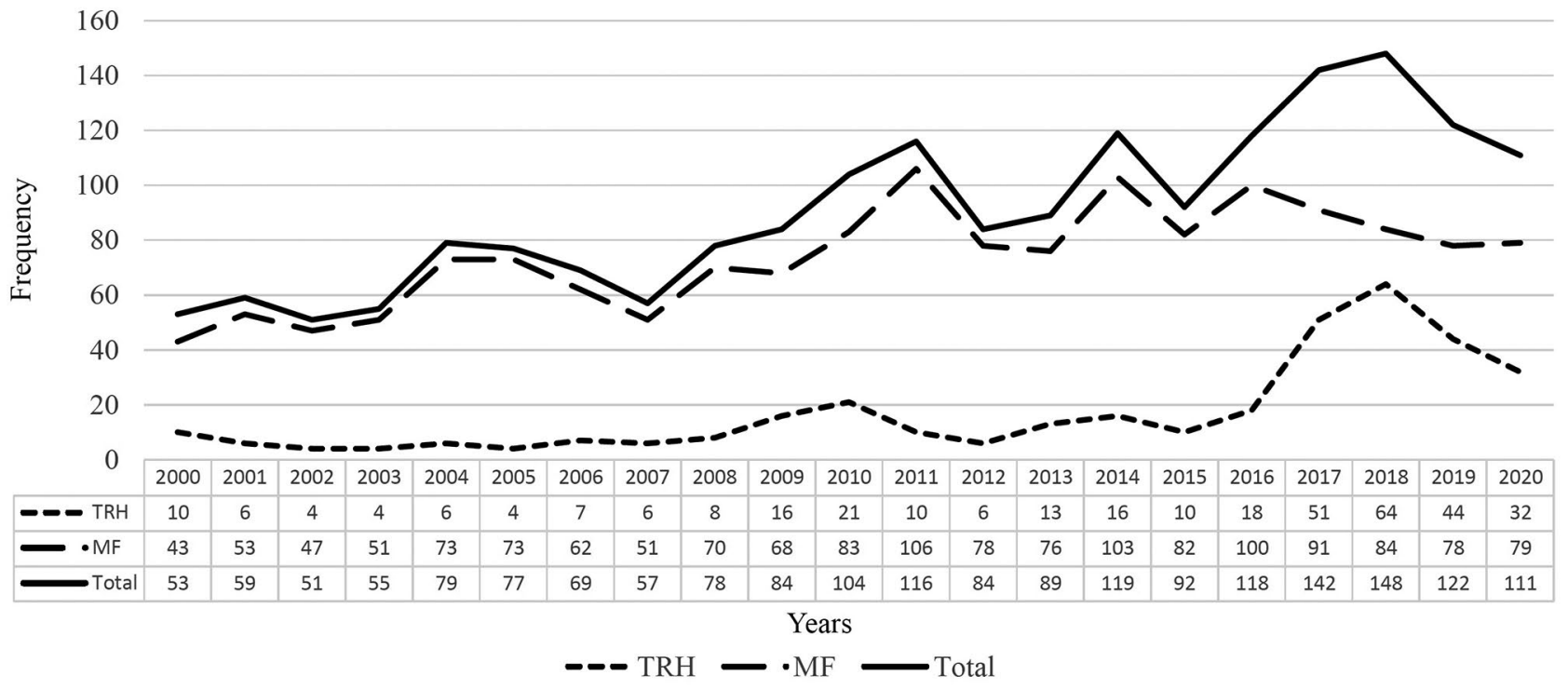




\begin{tabular}{|c|c|c|c|c|c|c|}
\hline \multicolumn{7}{|c|}{$\begin{array}{c}\text { TABLE II } \\
\text { ted values of the }\end{array}$} \\
\hline \multirow[b]{3}{*}{ Subgroups } & \multicolumn{3}{|c|}{ University Hospital } & \multicolumn{3}{|c|}{ Training and Research Hospital } \\
\hline & Observed & Expected & Residual & Observed & Expected & Residual \\
\hline & $\mathrm{n}$ & $\mathrm{n}$ & $\mathrm{n}$ & $\mathrm{n}$ & $\mathrm{n}$ & $\mathrm{n}$ \\
\hline Trauma & 415 & 435.8 & -20.8 & 121 & 100 & 21 \\
\hline Adult reconstruction and arthroplasty & 237 & 245.1 & -8.1 & 64 & 56.2 & 7.8 \\
\hline Spine surgery & 176 & 164.4 & 11.6 & 27 & 37.7 & -10.7 \\
\hline Sports injuries and arthroscopy & 152 & 153.5 & -1.5 & 36 & 35.2 & 0.8 \\
\hline Hand surgery & 118 & 111.7 & 6.3 & 20 & 25.6 & -5.6 \\
\hline General orthopedics & 119 & 108.6 & 10.4 & 14 & 24.9 & -10.9 \\
\hline Pediatric orthopedics & 106 & 99.3 & 6.7 & 16 & 22.8 & -6.8 \\
\hline Shoulder and elbow surgery & 79 & 88.4 & -9.4 & 29 & 20.3 & 8.7 \\
\hline Foot and ankle surgery & 82 & 85.3 & -3.3 & 23 & 19.6 & 3.4 \\
\hline Bone and soft tissue tumors & 67 & 58.9 & 8.1 & 6 & 13.5 & -7.5 \\
\hline Total & 1,551 & & & 356 & & \\
\hline$p$ value & & $0.725^{\star}$ & & & $0.003^{*}$ & \\
\hline
\end{tabular}

According to the subgroup distribution of the theses, university hospitals were not statistically significant $(\mathrm{p}=0.725)$ between observed and expected values, while training and research hospitals were found to be statistically significant $(\mathrm{p}=0.003)$. More theses were published than expected on orthopedic trauma, adult reconstruction and arthroplasty, sports injuries and arthroscopy, shoulder and elbow surgery, foot and ankle surgery in the training and research hospitals (Table II).

Based on the subgroups in which the theses were done according to the academic degree of the advisor, orthopedic trauma was the most studied subgroup for all academic degrees, while the least studied subgroups were shoulder and elbow surgery for professors $(n=43 ; 4.5 \%)$, and bone and soft tissue tumors for associate professors $(n=14 ; 2.2 \%)$ and others $(\mathrm{n}=4 ; 1.3 \%)$ (Table III).

According to the observed and expected value agreement of the thesis subgroups according to the publication year interval, a statistically significant difference was found in the observed and expected frequencies between 2000 and $2010(\mathrm{p}=0.015)$, while no statistically significant difference was found

\begin{tabular}{|c|c|c|c|c|c|c|c|c|}
\hline \multicolumn{9}{|c|}{$\begin{array}{l}\text { TABLE III } \\
\text { roups according }\end{array}$} \\
\hline \multirow[b]{2}{*}{ Subgroups } & \multicolumn{2}{|c|}{ Professor } & \multicolumn{2}{|c|}{ Associate professors } & \multicolumn{2}{|c|}{ Others } & \multicolumn{2}{|c|}{ Total } \\
\hline & $\mathrm{n}$ & $\%$ & $\mathrm{n}$ & $\%$ & $\mathrm{n}$ & $\%$ & $\mathrm{n}$ & $\%$ \\
\hline Trauma & 236 & 24.9 & 187 & 29.4 & 105 & 34.9 & 528 & 28 \\
\hline Adult reconstruction and arthroplasty & 179 & 18.9 & 97 & 15.2 & 24 & 8 & 300 & 15.9 \\
\hline Spine surgery & 107 & 11.3 & 73 & 11.5 & 21 & 7 & 201 & 10.7 \\
\hline Sports injuries and arthroscopy & 93 & 9.8 & 65 & 10.2 & 27 & 9 & 185 & 9.8 \\
\hline Hand surgery & 60 & 6.3 & 46 & 7.2 & 31 & 10.3 & 137 & 7.3 \\
\hline General orthopedics & 71 & 7.5 & 28 & 4.4 & 34 & 11.3 & 133 & 7.1 \\
\hline Pediatric orthopedics & 57 & 6 & 45 & 7.1 & 19 & 6.3 & 121 & 6.4 \\
\hline Shoulder and elbow surgery & 43 & 4.5 & 43 & 6.8 & 21 & 7 & 107 & 5.7 \\
\hline Foot and ankle surgery & 47 & 5 & 39 & 6.1 & 15 & 5 & 101 & 5.4 \\
\hline Bone and soft tissue tumors & 55 & 5.8 & 14 & 2.2 & 4 & 1.3 & 73 & 3.9 \\
\hline Total & 948 & 100 & 637 & 100 & 301 & 100 & 1,886 & 100 \\
\hline
\end{tabular}




\begin{tabular}{|c|c|c|c|c|c|c|}
\hline \multicolumn{7}{|c|}{ TABLE IV } \\
\hline \multirow[b]{3}{*}{ Subgroups } & \multicolumn{3}{|c|}{$2000-2010$} & \multicolumn{3}{|c|}{$2011-2020$} \\
\hline & Observed & Expected & Residual & Observed & Expected & Residual \\
\hline & $\mathrm{n}$ & $\mathrm{n}$ & $\mathrm{n}$ & $\mathrm{n}$ & $\mathrm{n}$ & $\mathrm{n}$ \\
\hline Trauma & 201 & 215.2 & -14.2 & 335 & 320.6 & 14.4 \\
\hline Adult reconstruction and arthroplasty & 120 & 121 & -1 & 181 & 180.3 & 0.7 \\
\hline Spine surgery & 98 & 81.2 & 16.8 & 105 & 120.9 & -15.9 \\
\hline Sports injuries and arthroscopy & 70 & 75.8 & -5.8 & 118 & 113 & 5 \\
\hline Hand surgery & 56 & 55.2 & 0.8 & 82 & 82.2 & -0.2 \\
\hline General orthopedics & 69 & 53.6 & 15.4 & 64 & 79.9 & -15.9 \\
\hline Pediatric orthopedics & 48 & 49 & -1 & 74 & 73 & 1 \\
\hline Shoulder and elbow surgery & 23 & 43.7 & -20.7 & 85 & 65 & 20 \\
\hline Foot and ankle surgery & 48 & 42.1 & 5.9 & 57 & 62.8 & -5.8 \\
\hline Bone and soft tissue tumors & 33 & 29.1 & 3.9 & 40 & 43.4 & -3.4 \\
\hline Total & 766 & & & 1,141 & & \\
\hline$p$ value & & $0.015^{*}$ & & & $0.160^{*}$ & \\
\hline
\end{tabular}

between 2010 and 2020 ( $p=0.160)$. Spine surgery was the most expected value between 2000 and 2010, and shoulder and elbow surgery between 2011 and 2020 (Table IV).

\section{DISCUSSION}

Bibliometric analysis is a useful tool for obtaining information about the current state of research in specific areas and allows researchers to identify and undertake new research areas. ${ }^{[9,10]}$ Residency theses are the mirror of the studies carried out in the field of health, which should have a high scientific research quality. Examining the bibliometric features of medical residency theses in the field of orthopedics and traumatology in our country is an important way to determine scientific field trends. The subject of thesis is significant in terms of the originality, quality, and acceptability of the thesis. The theses of residency in medicine are easily accessible in our country with the support of the National Thesis Center. Although it is easier to access and analyze published articles than theses, only $16 \%$ of 1,394 theses conducted between 1974 and 2012 could be published in the journals indexed in the PubMed database, according to a study conducted in Turkey. ${ }^{[7]}$ Therefore, evaluating the bibliometric features of theses made in the field of orthopedics and traumatology after 2000 would be more guiding for researchers to determine the current research topic trends.
According to the distribution of theses on type of institutions, we observed that the majority of the thesis were carried out in university hospitals until 2016. The increase in the number of orthopedics and traumatology quota in residency exams of Turkey as of 2010 showed its effect on the number of theses published in 2016. It is expected that nearly 267 theses would be published every year between 2021 and 2026 due to the increased number of orthopedics and traumatology residents.

Based on the distribution of the thesis over the years, we found that the theses on the orthopedic trauma subgroups had the highest rate during the study period. Studies on adult reconstruction and arthroplasty increased in the past five years (2016-2020) as a thesis topic. In the international orthopedic literature, arthroplasty is one of the trend topics as of 2017. The increase in the number of thesis publications in the field of arthroplasty as a thesis topic shows that the international trend also influences the selection of the topic. ${ }^{[1]]}$ Review of the literature reveals that similar research data on bibliometric analyses of theses in the field of orthopedics or the subject distributions of published articles are scarce and, therefore, it is very difficult to compare the findings of our study with the others. In the literature, there are many studies available in which the metrics of published articles were 
examined; however, subject distributions were not mentioned in these studies either. ${ }^{[12-14]}$

When the theses on the subject of bone and soft tissue tumors were examined, it was the least preferred thesis topic among all the subjects in our study. The rarity of bone and soft tissue tumors than other orthopedic conditions could be the reason for the scarcity. In addition, when the distribution by institutions was examined, only six (8.2\%) of the 73 theses were carried out in the training and research hospitals. The subject of orthopedics that requires the most multidisciplinary approach in the diagnosis and treatment process is undoubtedly orthopedic oncology. Referring patients with bone tumors to a specialist center that offers an early, multidisciplinary diagnosis-treatment approach and manages a large number of cases per year is a critical approach that increases the chance of survival. ${ }^{[15]}$ In the orthopedic oncology field, in which hospital facilities, surgical skills, and experience are expected at the upper level; however, scientific performance of training and research hospitals are deficient. Although bone and soft tissue tumor surgery are performed in other health institutions, it may not have been the subject of scientific research due to the insufficient number of patients, due to the rare occurrence of bone and soft tissue tumor patients and the collection of existing patients in specific centers.

According to the academic titles of thesis advisors, professors served as three-fold more and associate professors two-fold more than other academic positions in this study. This result is an expected one; it was directly related to the time spent in the academy.

The main limitation of the current study is that not all of the theses conducted in the field of orthopedics and traumatology were included in the National Thesis Center due to the deficiencies of secretariats and end-user problems.

In conclusion, the current study provides a comprehensive overview of the residency theses conducted over a 20-year period in the field of orthopedics and traumatology with the bibliometric analysis. According to the results, the orthopedic research trends which were differentiated over the years in our country were determined. The classification of the orthopedic thesis into subgroups shows in which orthopedics subfield research subjects are concentrated in our country and in which fields, research is needed. Thesis topic selection is an important step for both the research assistant and the advisor. Since our study reveals the development of the literature in our country and shows the research areas, we believe that the theses to be conducted in the future would create a roadmap and contribute to the selection of topics.

\section{Declaration of conflicting interests}

The authors declared no conflicts of interest with respect to the authorship and/or publication of this article.

\section{Funding}

The authors received no financial support for the research and/or authorship of this article.

\section{REFERENCES}

1. Lee KM, Ryu MS, Chung CY, Choi IH, Kwon DG, Kim TW, et al. Characteristics and trends of orthopedic publications between 2000 and 2009. Clin Orthop Surg 2011;3:225-9.

2. Moverley R, Rankin KS, McNamara I, Davidson DJ, Reed M, Sprowson AP. Impact factors of orthopaedic journals between 2000 and 2010: Trends and comparisons with other surgical specialties. Int Orthop 2013;37:561-7.

3. Brunod I, Rességuier N, Fabre A. Medical thesis publication and academic productivity of pediatric residents at the Medical University of Marseille: Associated factors and evolution over 20 years. Arch Pediatr 2020;27:408-15.

4. Pitchard A Statistical bibliography or bibliometrics. J Doc 1969;24:348-9.

5. Hood WW, Wilson CS. The literature of bibliometrics, scientometrics, and informetrics. Scientometrics 2001;52:291.

6. Mishra DK, Gawde M, Solanki MS. Bibliometric study of Ph.D. Thesis in English. Global Journal of Academic Librarianship 2014;1:19-36.

7. Koca K, Ekinci S, Akpancar S, Gemci MH, Erşen Ö, Akyıldız F. An analysis of orthopaedic theses in Turkey: Evidence levels and publication rates. Acta Orthop Traumatol Turc 2016;50:562-6.

8. Atik OŞ. What are the expectations of an editor from a scientific article? Jt Dis Relat Surg 2020;31:597-8.

9. De Battisti F, Salini S. Robust analysis of bibliometric data. Stat Methods Appl 2013;22:269-83.

10. Zyoud SH, Al-Jabi SW, Sweileh WM, Awang R. A Scopusbased examination of tobacco use publications in Middle Eastern Arab countries during the period 2003-2012. Harm Reduct J 2014;11:14.

11. Dutt-Mazumder A. Current trends in orthopedic research. Res Rev Orthop 2017;1:26.

12. Kennedy C, O Sullivan P, Bilal M, Walsh A. Ireland's contribution to orthopaedic literature: A bibliometric analysis. Surgeon 2013;11:267-71.

13. Saab M, Dartus J, Erivan R, Reina N, Ollivier M, Devos P. Publication output of French orthopedic and trauma surgeons: Quantitative and qualitative bibliometric analysis of their scientific production in orthopedics and other medical fields. Orthop Traumatol Surg Res 2019;105:1439-46.

14. Hui Z, Yi Z, Peng J. Bibliometric analysis of the orthopedic literature. Orthopedics 2013;36:e1225-32.

15. Redondo A, Bagué S, Bernabeu D, Ortiz-Cruz E, Valverde C, Alvarez R, et al. Malignant bone tumors (other than Ewing's): Clinical practice guidelines for diagnosis, treatment and follow-up by Spanish Group for Research on Sarcomas (GEIS). Cancer Chemother Pharmacol 2017;80:1113-31. 